\title{
Frequency and Type of Chromosomal Abnormalities in Childhood Acute Lymphoblastic Leukemia Patients in Kuwait: A Six-Year Retrospective Study
}

\author{
Soad Al-Bahar Adriana Zámečníkova Ramesh Pandita \\ Department of Hematology, Kuwait Cancer Control Center, Kuwait
}

\author{
Key Words \\ Childhood acute lymphoblastic leukemia • Genotype • \\ Chromosome anomalies
}

\begin{abstract}
Objective: To characterize the frequency of genetic profiles in pediatric acute lymphoblastic leukemia (ALL) patients in Kuwait. Subjects and Methods: This review presents the general cytogenetic characteristics of 164 pediatric patients diagnosed as having ALL in a 6-year period. Chromosomal and fluorescence in situ hybridization studies were made on bone marrow aspirates at diagnosis and during different stages of the disease. Results: Recurring aberrations, observed in 123 (75\%) patients, included hyperdiploidy $(n=68$, $41 \%)$, tetraploidy ( $n=12,7.3 \%)$, hypodiploidy ( $n=2,1.2 \%$ ), TEL-AML1 fusion ( $\mathrm{n}=11,7 \%)$, mixed-lineage leukemia rearrangement $(n=6,3.6 \%), t(9 ; 22)(n=4,2.4 \%), t(1 ; 19)(n=3$, $1.8 \%), t(8 ; 14)$ or $t(8 ; 22)(n=2,1.2 \%),+21(n=2,1.2 \%)$, del $(6)$ $(n=2,1.2 \%)$ and miscellaneous abnormalities $(n=9,5 \%)$. The highest observed numerical chromosome abnormality was high hyperdiploidy in 89 patients (54\%) with abnormal karyotype while the TEL-AML fusion was the highest observed structural abnormality. Conclusion: This study showed that clonal anomalies detected in pediatric ALL have shown correlations between specific abnormalities and clinicobiological characteristics of the patients.
\end{abstract}

Copyright $\odot 2010$ S. Karger AG, Basel

\begin{tabular}{ll}
\hline KARGER & (c) 2010 S. Karger AG, Basel \\
Fax +41613061234 & $1011-7571 / 10 / 0193-0176 \$ 26.00 / 0$ \\
$\begin{array}{l}\text { E-Mail karger@karger.ch } \\
\text { www.karger.com }\end{array}$ & $\begin{array}{l}\text { Accessible online at: } \\
\text { www.karger.com } / \mathrm{mpp}\end{array}$
\end{tabular}

\section{Introduction}

Acute lymphoblastic leukemia (ALL) is a malignant disorder of the bone marrow in which a lymphoid progenitor cell becomes genetically altered. It is the most common malignancy of childhood with an annual incidence rate of 3-4 cases per 100,000 children. Although there are few identified factors associated with an increased risk of developing ALL such as genetic, parental and environmental factors, the etiology of the disease remains largely unknown $[1,2]$. The disease has a bimodal distribution: a sharp peak in incidence among children aged 2-5 years [3], and the incidence is substantially higher in white than black children [4-6].

Molecular genetic techniques as well as better cytogenetic techniques revealed that the disease is heterogeneous in its pathogenesis. Numerous genetic alterations have been and continue to be discovered in ALL, and it has been repeatedly shown that specific genetic abnormalities are present in the majority of successfully karyotyped patients with ALL [3-6]. This study presents the general cytogenetic characteristics of pediatric patients diagnosed as having ALL within a 6-year period.

\section{Subjects and Methods}

Between 2002 and 2007, diagnostic karyotypes of 164 pediatric ALL patients (median age 5.9 years, range $0.4-15$ ) were investigated at Kuwait Cancer Control Center. Cytogenetic studies
RNDr. Adriana Zámečníkova, $\mathrm{PhD}$

Department of Hematology, Kuwait Cancer Control Center PO Box 42262

Shuwaikh 70653 (Kuwait)

Tel. +965 2482 1363, Fax +965 2484 1037, E-Mail annaadria@yahoo.com 
Table 1. Characteristics of the study population

\begin{tabular}{lcllllll}
\hline Subgroup & $\begin{array}{l}\text { Cases, } \\
\mathrm{n}(\%)\end{array}$ & $\begin{array}{l}\text { Sex ratio } \\
(\mathrm{M} / \mathrm{F})\end{array}$ & $\begin{array}{l}\text { Median } \\
\text { age, years }\end{array}$ & $\begin{array}{l}\text { Median } \\
\text { WBC, } \times 10^{9} / \mathrm{l}\end{array}$ & $\begin{array}{l}\text { Median } \\
\text { Hb, g/dl }\end{array}$ & $\begin{array}{l}\text { Median plate- } \\
\text { lets, } \times 10^{9} / 1\end{array}$ & $\begin{array}{l}3 \text {-year } \\
\text { EFS, \% }\end{array}$ \\
\hline Down syndrome & $12(7.3)$ & 3 & 7.5 & 8.4 & 6.5 & 62.7 & 50 \\
B-cell ALL & $143(87)$ & 1.5 & 6.2 & 40.7 & 7.4 & 46.9 & 75 \\
T-cell ALL & $21(13)$ & 6 & 7.7 & 78.1 & 11.2 & 75.3 & 62 \\
Normal & $41(25)$ & 1.5 & 6.4 & 48.6 & 9.6 & 60.7 & 78 \\
Abnormal & $123(75)$ & 1.6 & 6.2 & 26.3 & 10.0 & 62.3 & 68 \\
Total & $164(100)$ & 1.7 & 5.9 & 31.7 & 9.9 & 66.6 & 72 \\
\hline Hyperploidy & $68(41.5)$ & 1.5 & 4.6 & 15.4 & 9.7 & 58.1 & 82 \\
Tetraploidy & $12(7.3)$ & 1 & 6.5 & 81.4 & 11 & 75.4 & 60 \\
Hypodiploidy & $2(1.2)$ & 1 & 5.5 & 4.4 & 8.4 & 57.0 & 0 \\
TEL/AML1 & $11(6.7)$ & 0.6 & 5 & 6.2 & 6.3 & 35.5 & 45 \\
MLL/11q & $6(3.6)$ & 2 & 7.5 & 166.6 & 7.2 & 24.4 & 17 \\
t(1;19) & $3(1.8)$ & 2 & 7 & 7.8 & 4.0 & 30.0 & 0 \\
Ph & $4(2.4)$ & 4 & 11 & 30 & 10.6 & 83.0 & 0 \\
c-myc/8q24 & $2(1.2)$ & 1 & 11 & 35.4 & 7.4 & 70.5 & 0 \\
Others & $15(9.1)$ & 4 & 7.8 & 29.8 & 7.7 & 65.3 & 44 \\
\hline
\end{tabular}

$\mathrm{Hb}=$ Hemoglobin; $\mathrm{M}=$ male; $\mathrm{F}=$ female.

were performed on bone marrow aspirates on unstimulated direct and/or short-term cultures, using the G-banding technique. Whenever possible, 20-30 metaphases were studied, and karyotypes were described according to the International System of Human Cytogenetic Nomenclature [7]. To identify the cryptic $\mathrm{t}(12 ; 21)(\mathrm{p} 13 ; \mathrm{q} 21)$, the locus-specific identifier dual-color TELAML1 probe (Vysis, Downers Grove, Ill., USA) was applied to 40 patients with B-cell ALL according to the manufacturer's protocol. The event-free survival (EFS) was calculated from the date of diagnosis to the first of any event, or time from registration to last contact. Survival of cases without events was calculated from the date of diagnosis to the time of last contact.

\section{Results}

The incidence was higher in males $(\mathrm{n}=104,63 \%)$ than females $(n=60,37 \%)$. Of the 164 ALL patients, $143(87 \%)$ had B-cell and 21 (13\%) T-cell leukemia. The median white blood cell (WBC) count for the study population was $31.7 \times 10^{9} / 1$ (range $\left.0.5-300\right)$ and the median hemoglobin level was $9.9 \mathrm{~g} / \mathrm{dl}$ (range 2.7-13.9). The majority had $(142,86 \%)$ thrombocytopenia and presented with platelet counts less than $150 \times 10^{9} / 1$ (table 1 ). Clonal chromosome abnormalities were detected at presentation in 123 (75\%; 41 patients (25\%; 29 males, 12 females; median age 6.4 years) had apparently normal karyotypes (fig. 1).

Genomic Aberrations in Pediatric Acute Lymphoblastic Leukemia

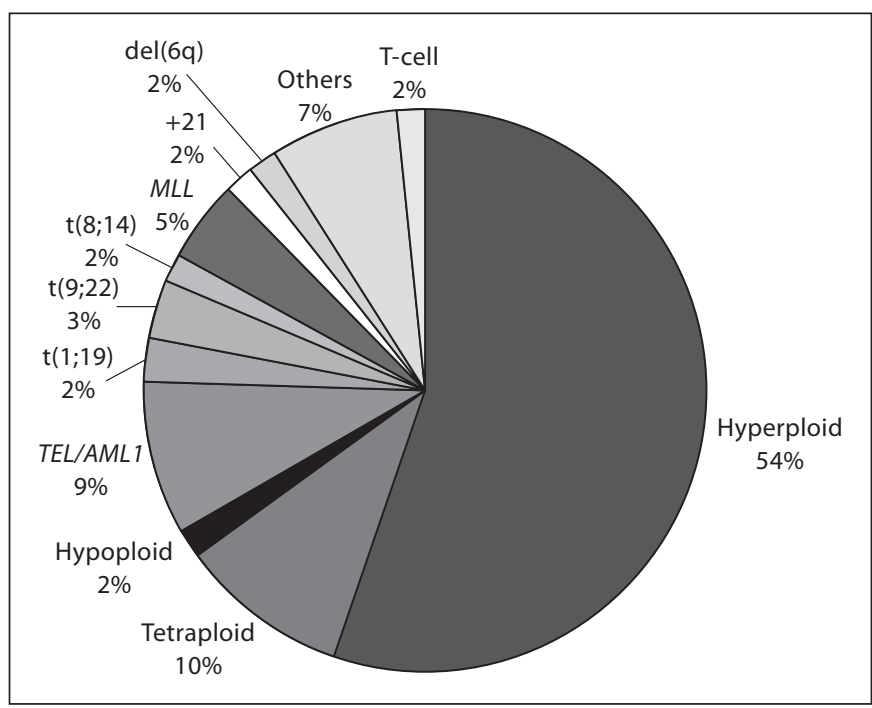

Fig. 1. Distribution of specific subgroups in the study population.

The occurrence of ALL was associated with characteristic peak incidences, and there were significant differences between mean ages of different genotypes (fig. 2). The highest frequency of high-hyperdiploidy and TEL$A M L 1$ fusion was found between the ages of 2 and 7, while the frequencies for other cytogenetic abnormalities such as $t(1 ; 19)$, mixed-lineage leukemia $(M L L)$ rearrangement 
Fig. 2. Age distribution of the study population.

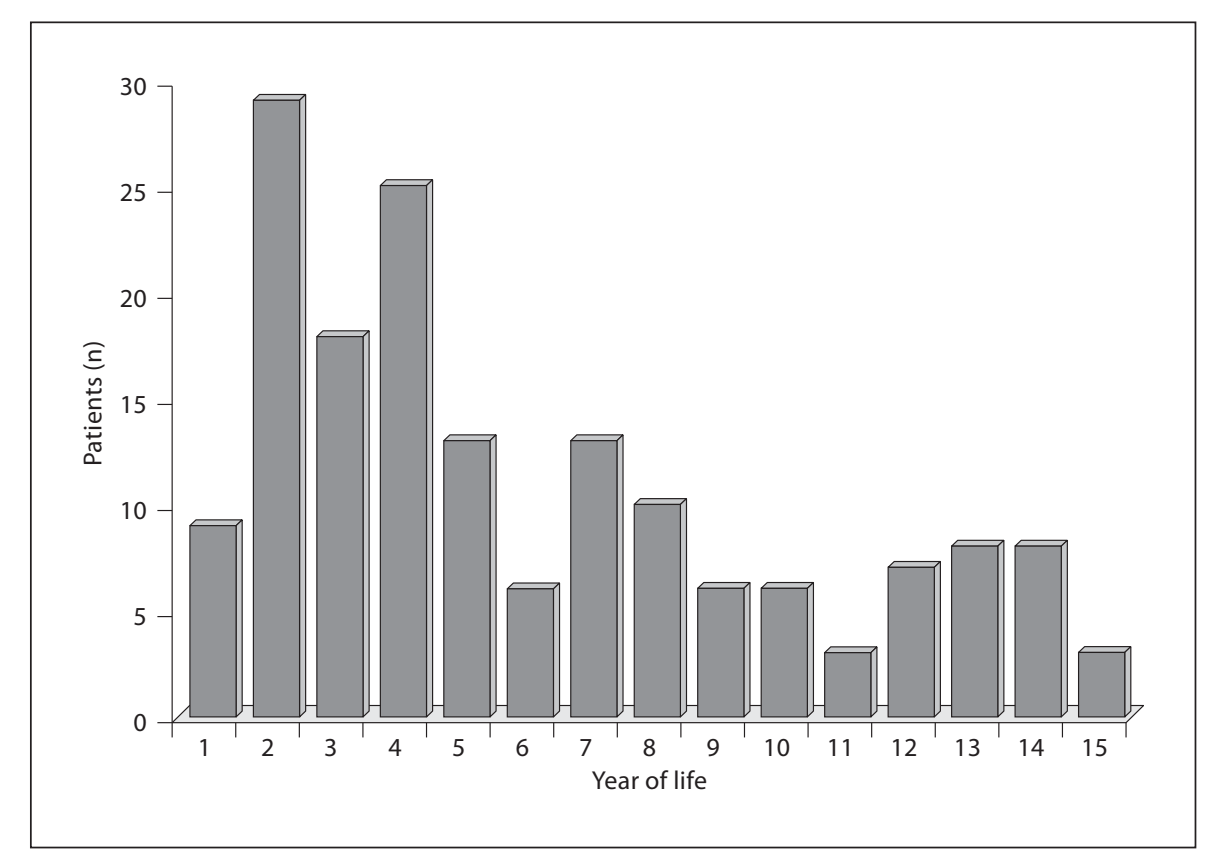

and Philadelphia $(\mathrm{Ph})$ were low in this age group and evenly distributed during childhood. It was noteworthy that $M L L$ rearrangement was not restricted to infancy and young age, as $50 \%$ of cases in this group were detected between the ages of 9 and 15 .

\section{Numerical Chromosomal Alterations}

Numerical chromosome abnormalities included: low hyperdiploidy (modal number 47-50), high or massive hyperdiploidy ( $>50)$, hypodiploidy (46 and lower), near-tetraploidy and gain or loss of a single chromosome. Modal chromosome numbers of $\leq 45$ were rare findings in our study population $(\mathrm{n}=2,1 \%)$. Hyperdiploidy without specific translocations was present in $68(41 \%)$ patients. All cases were of precursor B-cell type associated with moderate WBC counts at presentation, thrombocytopenia and Fab $\mathrm{L}_{1}$ or $\mathrm{L}_{2}$ morphology. The most frequently acquired numerical changes were $+21(\mathrm{n}=48),+X(\mathrm{n}=47),+14(\mathrm{n}=$ $43),+17(\mathrm{n}=40),+6(\mathrm{n}=38),+18(\mathrm{n}=37),+4(\mathrm{n}=35),+8$ $(\mathrm{n}=34)$ and $+10(\mathrm{n}=32)$. Among ploidy groups, 12 patients (14\%) had hyperdiploidy with modal numbers of $47-50$ with most frequently acquired numerical abnormalities of chromosomes 21 and $\mathrm{X}$. The complete remission rate for the total hyperdiploid group was $90 \%$, the median response duration of 43 months with 3-year EFS of 82\%. In about one third of all hyperdiploid cases $(n=22)$, additional rearrangements were observed, abnormalities of $1 \mathrm{q}$ being the most frequent $(n=18)$. Near-tetraploidy was ob- served in 12 cases. This group was characterized by high WBC (median $81.4 \times 10^{9} / 1$ ) and platelet counts (median $\left.75.2 \times 10^{9} / \mathrm{l}\right)$. In 5 patients, a mediastinal mass was present at diagnosis. The median response duration was 23 months with a 3-year EFS rate of less than $60 \%$.

\section{TEL-AML1 Rearrangement}

The TEL-AML1 (now known as ETV6-RUNX1) rearrangement was the most commonly observed structural abnormality identified by fluorescence in situ hybridization in $7 \%$ of the study population and $27 \%$ of the studied cases; $45 \%$ of cases had deletion of the remaining TEL allele. Additional anomalies were observed in $55 \%$ of cases (table 2). Children without additional anomalies tended to be younger (median age 4 vs. 6.2 years), had lower hemoglobin levels (median 5.4 vs. $9.9 \mathrm{~g} / \mathrm{dl}$ ) and platelets (median 26.6 vs. $115.5 \times 10^{9} / \mathrm{l}$ ) than children with additional karyotypic changes. Of 11 children, 5 relapsed within 1-3 years (median 32 months) including 4 of 5 children with additional anomalies (table 2).

\section{$t(1 ; 19)(23 ; p 13), t(9 ; 22)(q 34 ; q 11)$ and MLL}

\section{Rearrangements}

The $\mathrm{t}(1 ; 19)$ (q23;p13) translocation which involves fusion of the TCF3 gene on chromosome 19 to the PBX1 gene on chromosome 1 occurred in $1.8 \%$ of patients. All cases were pre-B ALL with positive CD10, CD19 and CD22 expression. This group of patients presented with 
Table 2. Clinical characteristics of patients with additional karyotypic abnormalities

\begin{tabular}{|c|c|c|c|}
\hline Age/sex & $\begin{array}{l}\text { WBC, } \\
\times 10^{9} / 1\end{array}$ & Chromosome abnormality & $\begin{array}{l}\text { EFS } \\
\text { months }\end{array}$ \\
\hline \multicolumn{4}{|l|}{ TEL } \\
\hline $8 / \mathrm{F}$ & 14.4 & $49-55, \mathrm{XX}, \operatorname{add}(6)(\mathrm{p} 25)$ & 43 \\
\hline $3 / \mathrm{M}$ & 10.2 & 46,XY,dup(1)(q21q44), $\operatorname{add}(4)(\mathrm{p} 16), \operatorname{del}(5)(\mathrm{q} ?),-9, \operatorname{del}(11)(\mathrm{q} 14), \operatorname{add}(17)(\mathrm{p} 13),-18,+21 \mathrm{c},+\operatorname{mar}$ & 32 \\
\hline $8 / \mathrm{F}$ & 11 & $46, \mathrm{XX}, \mathrm{t}(3 ; ?)(\mathrm{q} 27-28 ; ?), \operatorname{del}(6)(\mathrm{q} 21), \mathrm{t}(8 ; ?)(\mathrm{q} ? 21 ; ?), \operatorname{del}(12)(\mathrm{p} 11 \mathrm{p} 13), \operatorname{add}(14)(\mathrm{q} 32),+\mathrm{mar}$ & 41 \\
\hline 9/M & 208 & $46, \mathrm{XY}, \mathrm{t}(4 ; 11)(\mathrm{q} 21 ; \mathrm{q} 23) / 47, \mathrm{XX}, \mathrm{t}(4 ; 11)(\mathrm{q} 21 ; \mathrm{q} 23),+17$ & 5 \\
\hline $14 / \mathrm{M}$ & 205 & $\begin{array}{l}53, \mathrm{XY},+3, \mathrm{t}(4 ; 11)(\mathrm{q} 21 ; \mathrm{q} 23),+6,+7,+13,+16,+19,+\operatorname{mar} / 53, \mathrm{XY}, \mathrm{idem}, \mathrm{t}(1 ; 7)(\mathrm{q} 31 ; \mathrm{p} 22),+\operatorname{mar} 1-2 / \\
56, \mathrm{XY}, \operatorname{dup}(1)(\mathrm{q} 11 \mathrm{q} 43), \mathrm{t}(4 ; 11)(\mathrm{q} 21 ; \mathrm{q} 23),+6,+16,+18,+19,+20, \operatorname{add}(21)(\mathrm{q} 21),+22,+\operatorname{mar} 1-4\end{array}$ & 5 \\
\hline $15 / \mathrm{F}$ & 171 & $\begin{array}{l}\text { 45,XX,t(4;11)(q21;q23),-21/44,XX,idem,t(17;18)(p11;q11)/45,XX,idem,t(1;5)(q32;q35)/ } \\
44, X X, i d e m, t(9 ; 13)(\mathrm{q} 11 ; \mathrm{q} 34), \mathrm{t}(17 ; 18)(\mathrm{p} 11 ; \mathrm{q} 11)\end{array}$ & 4 \\
\hline $4 / \mathrm{M}$ & 36 & $46, \mathrm{XY}, \mathrm{t}(5 ; 11 ; 17)(\mathrm{q} 31 ; \mathrm{q} 23 ; \mathrm{q} 21-\mathrm{q} 22), \mathrm{i}(7)(\mathrm{q} 10), \operatorname{del}(12)(\mathrm{p} 13)$ & 8 \\
\hline \multicolumn{4}{|c|}{ бен(1- } \\
\hline $4 / \mathrm{M}$ & NA & $52-55, \mathrm{XY}, \mathrm{t}(9 ; 22)(\mathrm{q} 34 ; \mathrm{q} 11)$ & $14 \mathrm{BMT}$ \\
\hline $14 / \mathrm{M}$ & 30 & $51-54, X Y, \operatorname{del}(6)(21), \mathrm{t}(9 ; 22)(\mathrm{q} 34 ; \mathrm{q} 11)$ & $35 \mathrm{BMT}$ \\
\hline $14 / \mathrm{M}$ & 80 & $51-54, \mathrm{XY}, \mathrm{t}(9 ; 22)(\mathrm{q} 34 ; \mathrm{q} 11),+\operatorname{mar} 1-4$ & 17 T-cell \\
\hline $12 / \mathrm{M}$ & NA & $47, \mathrm{XY}, \mathrm{t}(9 ; 22)(\mathrm{q} 34 ; \mathrm{q} 11),+\operatorname{mar}$ & 13 \\
\hline \multicolumn{4}{|c|}{ : } \\
\hline $11 / \mathrm{F}$ & 56 & $46, \mathrm{XX}, \mathrm{t}(8 ; 22)(\mathrm{q} 24 ; \mathrm{q} 11), \operatorname{der}(15) \mathrm{t}(8 ; 15 ; 22)(\mathrm{q} 13 ; \mathrm{q} 26 ; \mathrm{q} 11-12)$ & $4+$ \\
\hline $11 / \mathrm{M}$ & 14.9 & $46, \mathrm{XY}, \mathrm{t}(8 ; 14)(\mathrm{q} 24 ; \mathrm{q} 32) / 46, \mathrm{XY}, \mathrm{idem}, \operatorname{der}(7) \mathrm{t}(1 ; 7)(\mathrm{q} 10 ; \mathrm{p} 10)$ & 10 \\
\hline
\end{tabular}

$\mathrm{BMT}=$ Bone marrow transplantation; NA = not assessed; + = EFS without event.

low WBC counts, and with the lowest median hemoglobin level (median $4 \mathrm{~g} / \mathrm{dl})$ and platelets $\left(30 \times 10^{9} / \mathrm{l}\right)$ among subgroups. The median EFS rate was 8 months, and ultimately all patients failed therapy within 2 years.

The $\mathrm{Ph}$ chromosome $\mathrm{t}(9 ; 22)$ translocation creating a hybrid $B C R-A B L$ gene was present in approximately $2 \%$ of children. Ph-positive ALL cases showed an absolute male predominance, and all patients in this group had a short remission duration, and ultimately all cases relapsed within 3 years including both patients who underwent bone marrow transplantation.

The $M L L$ gene located at band 11q23 was altered in $3.6 \%$ of cases. In 4 out of 6 cases the anomaly was associated with complex karyotypes. The complete remission rate was $67 \%$, with a median EFS of 10 months, and at present only 1 patient remains in remission.

\section{Miscellaneous Abnormalities}

Nonrecurring anomalies were detected in 15 patients (9\%) with abnormal karyotypes; 3 patients are still in re- mission and the remaining 4 patients relapsed within 448 months (median 19.7 months) indicating that children with miscellaneous chromosome anomalies tended to have an unfavorable clinical outcome.

T-Cell ALL. The diagnosis of T-cell ALL was made in 21 cases (13\%) associated with older age and a higher proportion of boys than in other karyotype groups (18 males, 3 females). Rearrangements in the 14q11-13 region, in which the T-cell receptor chain genes are located, were present in 2 cases. Further structural anomalies included: $\operatorname{del}(1)(\mathrm{p} 32), \operatorname{del}(6 \mathrm{q})$ and a $\mathrm{Ph}$ translocation associated with high-hyperdiploidy and marker chromosomes. The median EFS was 23 months with 3-year EFS rates of 44\% of those with an abnormal karyotype and $75 \%$ of those with a normal karyotype.

Down Syndrome. Of the 164 patients, 12 were identified with Down syndrome and ALL (ALL-DS). There was a clear male predominance, and DS patients were more likely to have normal cytogenetic results when compared with total patients (58 vs. $25 \%$ ). The DS patients tended 
to be older, and no ALL-DS patients were less than 2 years of age. Of the 7 patients with abnormal karyotype, 3 had near-triploidy/tetraploidy and in 4 miscellaneous chromosome anomalies were observed including $1 \mathrm{TEL} /$ AML1-positive patient with multiple numerical and structural anomalies involving chromosomes 1, 4, 5, 9, 11,17 and 18 (table 2). No translocations associated with adverse outcome such as $t(9 ; 22), t(4 ; 11)$ or $t(1 ; 19)$ were presented. A notable finding in this group was a TELAML1 fusion in a 3-year-old male and complex karyotype as TEL-AML1 rearrangements (table 2) which appear to be uncommon in the ALL-DS population. The DS patients were more likely to suffer leukemic relapse than non-DS patients as 6 of 12 patients $(50 \%)$ relapsed with a median of 16 months. ALL-DS patients were more likely to have normal cytogenetic results when compared with total patients (58 vs. $25 \%$ ). ALL-DS patients were more likely to suffer leukemic relapse than ALL-non-DS patients as 6 of 12 patients (50\%) relapsed with a median of 16 months (range 4-32 months).

\section{Discussion}

While the cause in most cases of childhood leukemia is not known, certain factors such as susceptibility or environmental influences have been suggested. Evidence in support of this theory comes from the observation that the type and frequency of ALL vary by geographic region [4-6] and ethnicity [8].

From January 2002 to 2007, a diagnosis of ALL was made in 205 children (34 cases/year). While the population of Kuwait is about 3.05 million (1.92 million males; 1.13 million females; sex ratio 1.7), only about one quarter $(n=692,000$; sex ratio 1.05) of the population are children [9], making the annual incidence rate of childhood ALL about 5 cases (4.9) per 100,000 children. The presenting ages at diagnosis in our study group did not differ substantially from those of children with ALL reported in previous studies. A notable exception was the older age of patients in the group with $M L L$ rearrangement as 5 out of 6 patients were older than 1 year at diagnosis (table 2). The observed $75 \%$ frequency of genetic abnormalities in our study population was consistent with those of previous reports [10-14]. The difference between the findings of this study and previous reports is the relatively higher frequency of hyperdiploid cases (41.5\%) seen in this cohort, as in most of the reported series. A decreased prevalence of hyperdiploidy in patients with DS is consistent with recent reports [15-19] that showed a significantly lower frequency of hyperdiploid cases in ALL-DS patients suggesting this may contribute to a poorer outcome of patients in this group. Further differences were observed in the clinical outcome of children with TEL$A M L 1$ rearrangement (table 2). While only few reports [20-22] questioned the favorable prognosis for TELAML1-positive ALL, in our patients, 5 out 11 children relapsed, most likely due to the presence of additional chromosome anomalies. The current study confirmed the specific clinical features of patients with $\mathrm{t}(9 ; 22), M L L$ and $c-m y c$ rearrangements including high leukocyte counts and older age at diagnosis. The clinical outcome for patients in all 4 subgroups has been very poor indicating that the treatment for this category of patients remains a challenge. Maybe, ongoing cytogenetic analysis can identify new nonrandom chromosome aberrations and uncover a previously unrecognized diversity among patients [23-25].

\section{Conclusion}

The results of this study confirmed that clonal abnormalities detected in childhood ALL have shown correlations between specific recurrent chromosomal abnormalities and clinicobiological characteristics of the patients.

\section{Acknowledgment}

The authors would like to thank Lovely Annie Samuel, Neelima Kota and Liby John for their assistance in data collection.

References

$\checkmark 1$ Pui CH, Relling MV, Downing JR: Acute lymphoblastic leukemia. N Engl J Med 2004; 350:1535-1548.

2 Carroll WL, Bhojwani D, Min DJ: Pediatric acute lymphoblastic leukemia. Hematology 2003;1:102-131.

3 Erik F, Kjeld S: The incidence peaks of the childhood acute leukemias reflect specific cytogenetic aberrations. J Pediatr Hematol Oncol 2006;28:486-495.

4 Matasar MJ, Ritchie EK, Consedine N: Incidence rates of the major leukemia subtypes among US Hispanics, Blacks, and non-Hispanic Whites. Leuk Lymphoma 2006;47: 2365-2370.

5 Michel G, von der Weid NX, Zwahlen M, Swiss Paediatric Oncology Group (SPOG): Incidence of childhood cancer in Switzerland: the Swiss childhood cancer registry. Pediatr Blood Cancer 2008;50:46-51. 
6 Bhatia S, Sather HN, Heerema NA: Racial and ethnic differences in survival of children with acute lymphoblastic leukemia. Blood 2002;100:1957-1964.

7 Mitelman F (ed): ISCN 1995: An International System for Human Cytogenetic Nomenclature. Basel, Karger, 1995.

$>8$ Pui CH, Sandlund JT, Pei D: Results of therapy for acute lymphoblastic leukemia in black and white children. JAMA 2003;290: 2001-2007.

9 Ministry of Planning: Annual Statistical Abstract, ed 43. Kuwait, 2006, p 52.

10 Andreasson P, Hoglund M, Bekassy AN: Cytogenetic and FISH studies of a single center consecutive series of 152 childhood acute lymphoblastic leukemias. Eur J Haematol 2000;65:40-51.

11 Silverman LB, Gelber RD, Dalton VK: Improved outcome for children with acute lymphoblastic leukemia: results of Dana-Farber Consortium Protocol 91-01. Blood 2001;97: 1211-1218.

- 12 Pui CH, Sandlund JT, Pei D: Improved outcome for children with acute lymphoblastic leukemia: results of Total Therapy Study XIIIB at St Jude Children's Research Hospital. Blood 2004;104:2690-2696.
13 Levy MDE, Barr AR, Clavell L: Results of the Dana-Farber Cancer Institute ALL Consortium Protocol 95-01 for children with acute lymphoblastic leukemia. Blood 2007;109. 896-904.

14 Schneider NR, Carroll AJ, Shuster JJ: New recurring cytogenetic abnormalities and association of blast cell karyotypes with prognosis in childhood T-cell acute lymphoblastic leukemia: a Pediatric Oncology Group report of 343 cases. Blood 2000;96:25432549.

15 Whitlock JA: Down syndrome and acute lymphoblastic leukaemia. Br J Haematol 2006;135:595-602.

16 Dördelmann M, Schrappe M, Reiter A: Down's syndrome in childhood acute lym phoblastic leukemia: clinical characteristics and treatment outcome in four consecutive BFM trials: Berlin-Frankfurt-Munster Group. Leukemia 1998;12:645-651.

17 Bassal M, La MK, Whitlock JA: Lymphoblast biology and outcome among children with DS and ALL treated on CCG-1952. Pediatr Blood Cancer 2005;44:21-28.

18 Whitlock JA, Sather HN, Gaynon P: Clinical characteristics and outcome of children with Down syndrome and acute lymphoblastic leukemia: a Children's Cancer Group study. Blood 2005;106:4043-4049.

19 Lanza C, Volpe G, Basso G: The common $T E L-A M L 1$ rearrangement does not represent a frequent event in acute lymphoblastic leukaemia occurring in children with Down syndrome. Leukemia 1997;11:820-821.
20 Shurtleff SA, Buijs A, Behm FG: TEL/AML1 fusion resulting from a cryptic $\mathrm{t}(12 ; 21)$ is the most common genetic lesion in pediatric ALL and defines a subgroup of patients with an excellent prognosis. Leukemia 1995;9: 1985-1989.

21 Loh ML, Goldwasser MA, Silverman LB, et al: Prospective analysis of TEL/AML1-positive patients treated on Dana-Farber Cancer Institute Consortium Protocol 95-01. Blood 2006;107:4508-4513.

22 Holleman A, den Boer ML, de Menezes RX, et al: TEL/AML-1 dimerizes and is associated with a favorable outcome in childhood acute lymphoblastic leukemia. Blood 1996; 88:4252-4258.

23 Cheng KM, Kazemier C, Janka-Schaub GE: The expression of 70 apoptosis genes in relation to lineage, genetic subtype, cellular drug resistance, and outcome in childhood acute lymphoblastic leukemia. Blood 2006;107: 769-776.

24 Ross ME, Zhou X, Song G: Classification of pediatric acute lymphoblastic leukemia by gene expression profiling. Blood 2003;102: 2951-2959.

25 Flotho C, Coustan-Smith E, Pei D: A set of genes that regulate cell proliferation predicts treatment outcome in childhood acute lymphoblastic leukemia. Blood 2007;110:12711277. 